\title{
PEMETAAN QUDRAH MAHASISWA PROGRAM STUDI PENDIDIKAN AGAMA ISLAM DALAM MEMBACA DAN MENULIS AL-QUR'AN
}

\author{
Shobah Shofariyani Iryanti ${ }^{1}$, Ari Khairurrijal Fahmi \\ ${ }^{1}$ Program Studi Pendidikan Agama Islam, Universitas Muhammadiyah \\ Prof. DR. HAMKA Jakarta \\ ${ }^{2}$ Program Studi Pendidikan Bahasa Arab, Universitas Muhammadiyah \\ Prof. DR. HAMKA Jakarta \\ Email: shobah_si@,uhamka.ac.id, HP; 081310423602
}

\begin{abstract}
Being able to read and write the Qur'an is an indicator of graduates of Islamic religious education study programs. However, many of the students were negligent in carrying out the obligation to read the Qur'an with quite varied reasons. Therefore, this study aims to analyze the qudrah of students in reading and writing the Qur'an, precisely in the UHAMKA Islamic religious education study program. This research uses a qualitative approach with a descriptive type. Data collection techniques used were tests and interviews. The results showed that the majority of first semester students in classes A, B, C, and D received a predicate of $49 \%$. For the written test results showed $47 \%$ were in the category of inappropriate and less neat. The factors that are quite influential are motivation in self, school origin, and parents' encouragement. The results of this study have implications for the need for innovative formulations of learning to read and write the Qur'an for students so as to improve understanding and basic skills in reading and writing the Qur'an.
\end{abstract}

Keywords: Qudrah student, reading the Qur'an, writing the Qur'an

\begin{abstract}
Abstrak
Mampu membaca dan menulis Al-Qur'an adalah indikator lulusan program studi pendidikan agama Islam. Namun demikian, banyak dari kalangan mahasiswa yang lalai dalam melaksanakan kewajiban membaca al-Qur'an dengan alasan yang cukup variatif. Oleh sebab itu, penelitian ini bertujuan menganalisis qudrah mahasiswa dalam membaca dan menulis al-Qur'an, tepatnya di program studi pendidikan agama Islam UHAMKA. Penelitian ini menggunakan pendekatan kualitatif dengan jenis deskriptif. Teknik pengumpulan data yang digunakan adalah tes dan wawancara. Hasil penelitian menunjukkan bahwa mayoritas mahasiswa semester I kelas A, B, C, dan D mendapat predikat kurang lancar sebesar $49 \%$. Untuk hasil tes tulis menunjukkan $47 \%$ terdapat pada kategori kurang tepat dan kurang rapi. Adapun faktor yang cukup berpengaruh adalah motivasi dalam diri, asal sekolah, dan dorongan orang tua. Hasil penelitian ini berimplikasi pada kebutuhan akan formulasi inovasi pembelajaran membaca dan menulis Al-Qur'an bagi mahasiswa sehingga dapat meningkatkan pemahaman dan keterampilan dasar dalam membaca dan menulis al-Qur'an.
\end{abstract}

Kata Kunci: Kemampuan Mahasiswa, Membaca al-Qur'an, Menulis alQur'an 


\section{PENDAHULUAN}

Al-Qur'an bukanlah hiasan dalam rumah melainkan kitab suci yang menjadi hudan umat Islam dalam mengarungi kehidupan baik di dunia dan maupun akhirat. Para ulama Fikih mendeskripsikan Al-Qur'an sebagai kalamullah yang diturunkan kepada Nabi Muhammad saw. secara berangsur-angsur melalui wasilah Malaikat Jibril didahului dengan QS. Al-Fatihah dan diakhiri dengan QS. An-Naas dan akan mendapat ganjaran pahala bagi yang membacanya (Syarbini dan Jamhari, 2012).

Eksistensi Al-Qur'an telah mendapat jaminan dari Allah sebagaimana termaktub dalam QS. Al-Hijr: 9 yang artinya "Sesungguhnya kami yang menurunkan Al-Qur'an dan Kamilah pemelihara-pemeliharanya". Selain penjagaannya yang dijamin oleh Allah Swt. keistimewaan Al-Qur'an juga terletak pada keindahan susunan dan gaya bahasa pada setiap ayat dan cakupan isinya yang tiada tertandingi. Ini adalah bukti akan kekuasaan Allah sang pencipta. Kemudian apa tugas manusia terhadap Al-Qur'an? Apakah cukup hanya sebatas memiliki Al-Qur'an?

Setiap individu muslim memiliki kewajiban untuk membaca Al-Qur'an sebagai bentuk realisasi dari iman kepada kitab-kitab Allah. Allah akan mengangkat derajat orang yang membaca Al-Qur'an dengan ikhlas, memperoleh ketenteraman dan rahmat dari Allah Swt. Selain itu, Al-Qur'an juga akan menjadi penolong pembacanya pada hari kiamat kelak, hidup bersama malaikat dan bagi yang belum lancar dalam membacanya akan mendapatkan dua pahala, orang yang membaca satu huruf dalam al-Qur'an akan mendapat pahala sepuluh kebajikan. Perihal tersebut merupakan keutamaan dalam membaca Al-Qur'an. (Nizhan, 2008).

Keistimewaan membaca Al-Qur'an sebagaimana di atas dirasakan langsung oleh 80 santri Pondok Pesantren ar-Rohmah Ngawi bahwa mengimani al-Qur'an dengan sistem membaca dan mengerti arti yang tersirat memiliki dampak yang cukup signifikan dalam menurunkan tingkat kecemasan santri (Mar'ati \& Chaer, 2017). Pada penelitian lain disebutkan bahwa kultur membaca Al-Qur'an sebelum belajar berdampak pada tingkat kognitif siswa (Akbar, 2019). Selain itu, pada penelitian eksperimen yang dilakukan atas 30 responden dengan rentang usia 40-70 tahun menunjukkan bahwa penurunan tekanan darah pada pasien hipertensi dirasakan ketika pasien membaca al-Qur'an. (Irawati \& Lestari, 2017). Dengan demikian dapat diketahui bahwa membaca Al-Qur'an membawa efek dalam aspek spiritual, psikologis, edukasi, dan juga kesehatan bagi para pembacanya.

Membaca Al-Qur'an bukan hanya asal membaca. Qudrah membaca Al-Qur'an terdiri dari tahapan-tahapan tertentu, yakni tahap kemampuan melafalkan huruf-huruf sesuai dengan makhraj dan sifatnya sehingga huruf yang disebutkan sesuai dengan orisinalitas huruf-huruf AlQur'an itu sendiri, kemampuan membaca Al-Qur'an sesuai dengan kaidah ilmu tajwid 
merupakan bentuk pemeliharaan al-Qur'an dari kesalahan dan perubahan (Nizhan, 2008). Indeks mampu dalam membaca Al-Qur'an adalah melafalkan bunyi huruf Al-Qur'an, memilah harokat, dan membaca urutan huruf menjadi kata (Suriah, 2018).

Qudrah dalam membaca Al-Qur'an memiliki afiliasi dengan kemahiran menulis AlQur'an. Sebagaimana hasil penelitian yang dilakukan pada 26 siswa MI Quraniyah 8 Palembang menampilkan data bahwa ada korelasi antara siswa yang mendapat nilai baik dalam membaca Al-Qur'an terhadap ketepatan dalam menulis Al-Qur'an (Aquami, 2017).

Kemampuan menulis Al-Qur'an memiliki peran pokok dalam hal fahmil qur'an. Kemampuan menulis Al-Qur'an adalah keterampilan menuliskan huruf-huruf hijaiyah dalam Al-Qur'an sesuai dengan tata cara penulisan yang benar. Beberapa hal yang harus diperhatikan dalam penulisan ayat Al-Qur'an, yaitu: 1) Menulis huruf Arab diawali dari sisi kanan, 2) Dari keseluruhan huruf hijaiyah, ada huruf yang dapat disambung dan adapula huruf yang ditulis terpisah, 3) Perhatikan penulisan kata ketika berada di awal, tengah dan di akhir.

Berikut beberapa parameter menulis Al-Qur'an, antara lain: 1) mampu menulis satu huruf, dua huruf dan seterusnya, 2) mampu menulis huruf dengan menggunakan harokat fathah, dhommah, dan kasroh, 3) mampu menuliskan dua kalimat atau lebih, 4) mampu meniru ayat AlQur'an dengan melihat teks Al-Qur'an, 5) mampu menulis ayat yang dibacakan secara imla atau dikte (Tim Laboratorium FTIK, 2015). Menelusuri penelitian yang dilakukan terhadap peserta didik kelas X SMA IT Ponpes Al-Mujtama' Al-Islami memberikan hasil bahwa metode imla cukup efektif diterapkan untuk melatih keterampilan menulis tulisan berbahasa Arab (KESUMA, 2016).

Peningkatan kemampuan membaca dan menulis Al-Quran merupakan tuntutan mendesak bagi institusi yang akan mencetak lulusan pendidikan agama Islam termasuk Universitas Muhammadiyah Prof. DR. HAMKA sebagai perguruan tinggi pendidikan Islam khususnya lulusan Program Studi Pendidikan Agama Islam. Karena cakap dalam membaca dan menulis Al-Qur'an dengan baik dan benar merupakan prasyarat dalam mencetak generasi muslim. Sungguh ironi jika ditemukan guru Pendidikan Agama Islam belum mampu membaca Al-Qur'an sesuai dengan makhraj dan sifat huruf serta kaidah-kaidah tajwid. Begitupula dalam hal menulis Al-Qur'an, guru Pendidikan Agama Islam juga dituntut untuk mampu menulis Al-Qur'an sebagai wujud skill pedagogik guru Pendidikan Agama Islam (Aeni, 2015).

Namun demikian, dalam beberapa waktu belakangan ini banyak orang yang lalai khususnya kalangan mahasiswa dalam melaksanakan kewajiban untuk membaca Al-Qur'an dengan alasan yang cukup variatif, seperti kurangnya semangat yang muncul dalam diri, kurangnya pengetahuan tentang ilmu tajwid sebagai ilmu pokok dalam membaca Al-Qur'an 
(Ariani, 2017), tugas yang begitu menumpuk, wasting time untuk games online dan media sosial lainnya. Inilah kultur generasi penerus bangsa saat ini yang berada di zona keprihatinan. Semua alasan tersebut bermuara pada pertanyaan, apakah tidak ada keinginan (iradah) dalam diri untuk membaca Al-Qur'an atau tidak adanya kemampuan (qudrah) dalam membaca Al-Qur'an?

Kelalaian dalam membaca Al-Qur'an akan berimbas pada wilayah ketidakmampuan. Dalam penelitian yang dilakukan terhadap mahasiswa Fakultas Kedokteran Universitas YARSI ditemukan mahasiswa yang masih kurang fasih dalam membaca Al-Qur'an dan kurang tepat dalam menulis Al-Qur'an (-, 2019).

Berdasarkan uraian di atas, peneliti tertarik untuk mengetahui bagaimana kemampuan (qudrah) mahasiswa Program Studi Pendidikan Agama Islam Universitas Muhammadiyah Prof. DR. HAMKA dalam membaca dan menulis Al-Qur'an tahun akademik 2019/2020? Penelitian ini diharapkan akan menghasilkan data mengenai pemetaan qudrah mahasiswa dalam membaca dan menulis Al-Qur'an. Selanjutnya data ini dapat dijadikan bahan formulasi untuk konsep inovasi pembelajaran baca tulis Al-Qur'an di era revolusi industri sehingga dapat menyentuh aspek motivasi dan penguatan pemahaman kaidah-kaidah dalam membaca dan menulis AlQur'an.

\section{METODE}

Penelitian ini merupakan penelitian kualitatif dengan jenis deskriptif. Jenis penelitian deskriptif kualitatif yang digunakan pada penelitian ini dimaksudkan untuk mendapatkan fakta mengenai bagaimana qudroh mahasiswa dalam membaca dan menulis Al-Qur'an secara mendalam dan komprehensif. Sumber data dalam penelitian ini adalah mahasiswa semester I kelas A, B, C, dan D Program Studi Pendidikan Agama Islam Universitas Muhammadiyah Prof. DR. HAMKA yang berjumlah 136 mahasiswa. Untuk mencapai tujuan dalam penelitian ini maka ditempuh langkah-langkah pengumpulan data sebagai berikut: Pertama, tes yang terdiri dari tes lisan tes tulis. Tes lisan untuk kemampuan dalam membaca Al-Qur'an dan tes tulis untuk kemampuan menulis Al-Qur'an. Kedua, wawancara mahasiswa Program Studi Pendidikan Agama Islam untuk memperoleh informasi yang lebih mendalam serta memperkuat hasil tes.

Berikut panduan dalam menilai qudrah mahasiswa dalam membaca Al-Qur'an dapat dilihat pada tabel 1 di bawah ini: 
Tabel 1 Kriteria Nilai Mahasiswa dalam Hal Membaca Al-Qur'an

\begin{tabular}{lll}
\hline No & Nilai & Kriteria \\
\hline 1 & $85-100$ & Lancar \\
2 & $70-84$ & Kurang Lancar \\
3 & $<70$ & Tidak Lancar \\
\hline
\end{tabular}

Tabel 2 Kriteria Nilai Mahasiswa dalam Hal Menulis Al-Qur'an

\begin{tabular}{lll}
\hline No & Nilai & Kriteria \\
\hline 1 & $85-100$ & Tepat dan Rapi \\
2 & $70-84$ & Kurang tepat dan Kurang rapi \\
3 & $<70$ & Tidak tepat dan Tidak rapi \\
\hline
\end{tabular}

Untuk tahap selanjutnya adalah tahap analisis data, peneliti menggunakan analisa data Huberman yang terdiri dari pengumpulan data, reduksi data, display data, dan verifikasi data.

\section{HASIL DAN PEMBAHASAN}

Hasil mengenai qudrah mahasiswa semester I kelas A, B, C, dan D Program Studi Pendidikan Agama Islam Universitas Muhammadiyah Prof. DR. HAMKA dalam membaca AlQur'an diperoleh data bahwa ada tingkatan kemampuan mulai dari yang tidak dapat membaca Al-Qur'an termasuk kategori tidak lancar, lancar tetapi kurang tepat dalam membacanya termasuk kategori kurang lancar hingga yang dapat membaca dengan baik dan benar termasuk kategori lancar. Untuk rincian persentase qudrah mahasiswa dalam membaca Al-Qur'an dapat dilihat pada gambar 1 di bawah ini.

Gambar 1: Qudrah Mahasiswa dalam Membaca Al-Qur'an Tahun Akademik 2019/2020

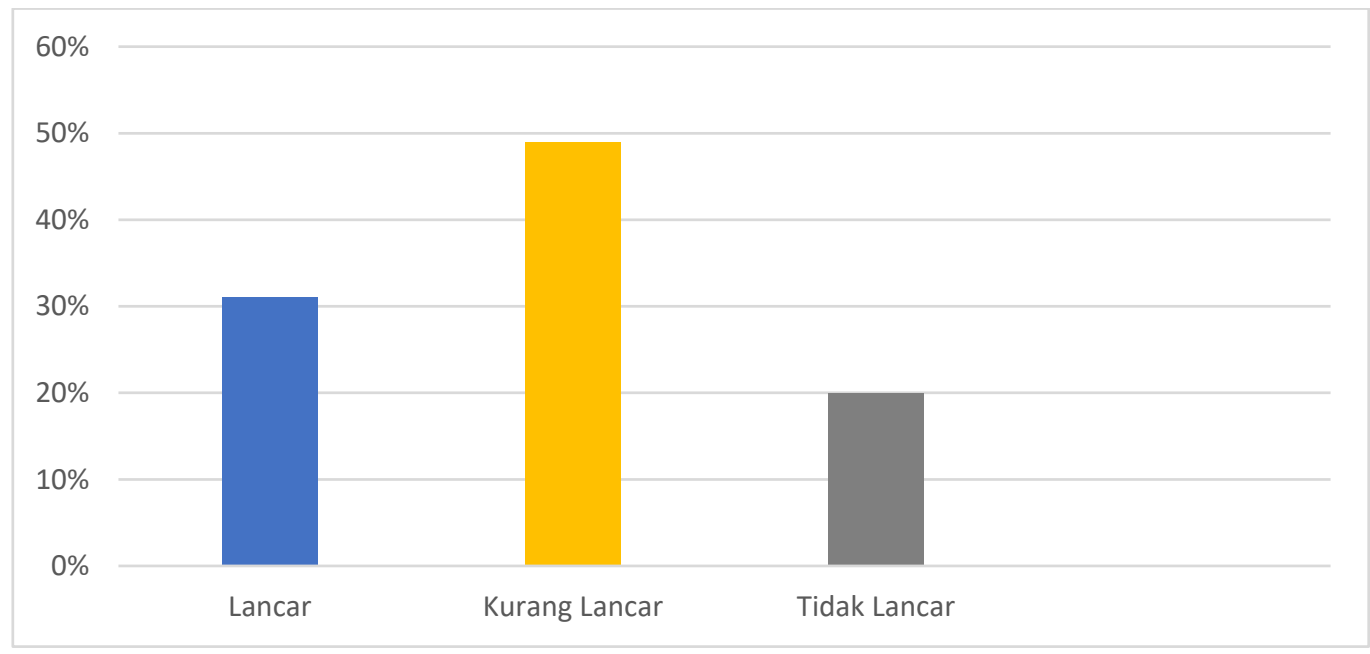


Berdasarkan gambar di atas, terlihat bahwa persentase tertinggi sebesar $49 \%$ qudrah mahasiswa semester I kelas A, B, C, dan D dalam membaca Al-Qur'an terdapat pada kategori kurang lancar dengan skor nilai tes lisan 70-84. Sedangkan mahasiswa dengan range skor nilai tes lisan 85-100 mendapat predikat lancar berjumlah $31 \%$ dan predikat tidak lancar dengan range skor nilai tes lisan $<70$ sebesar $20 \%$.

Selain melakukan tes lisan, peneliti juga mewawancarai latar belakang kemampuan mahasiswa dengan predikat lancar dalam membaca Al-Qur'an berupa dorongan orang tua untuk mempelajari Al-Qur'an sejak kecil dan mewajibkan untuk membaca Al-Qur'an setiap harinya, asal sekolah yang berbasis keislaman menuntut siswa siswinya untuk mampu dalam membaca Al-Qur'an. Beberapa hal tersebut merupakan faktor eksternal yang menyebabkan mahasiswa lancar dalam membaca Al-Qur'an. Faktor eksternal bukanlah penentu utama karena kesadaran diri menjadi pendorong yang kuat untuk mau belajar Al-Qur'an dan mau membaca Al-Qur'an. Inilah yang terjadi pada beberapa mahasiswa yang tergolong pintar dalam ilmu tajwid tetapi kurang lancar dalam membaca Al-Qur'an karena keilmuan yang dimiliki tidak dibarengi dengan upaya untuk memeliharanya dengan cara rajin membaca Al-Qur'an setiap harinya. Alasan yang diungkapkan mahasiswa beragam mulai dari tugas kuliah yang menumpuk dan hasrat untuk bermain games online atau media sosial lainnya.

Faktor yang sama juga terungkap dalam hasil penelitian yang dilakukan pada siswa kelas X SMK Muhammadiyah 1 Taman yang mendapatkan nilai baik dalam tes membaca Al-Qur'an karena dipengaruhi oleh faktor internal berupa minat dalam diri yang sudah muncul sejak kecil serta peranan dan perhatian yang diberikan orang tua khususnya dalam mempelajari Al-Qur'an sebagai faktor eksternal yang menguatkan faktor internal (Wibawa, 2018).

Selanjutnya hasil mengenai qudrah mahasiswa semester I kelas A, B, C, dan D Program Studi Pendidikan Agama Islam Universitas Muhammadiyah Prof. DR. HAMKA dalam menulis Al-Qur'an tervisualisasi pada gambar 2 di bawah ini. 
Gambar 2: Qudrah Mahasiswa dalam Menulis Al-Qur'an Tahun Akademik 2019/2020

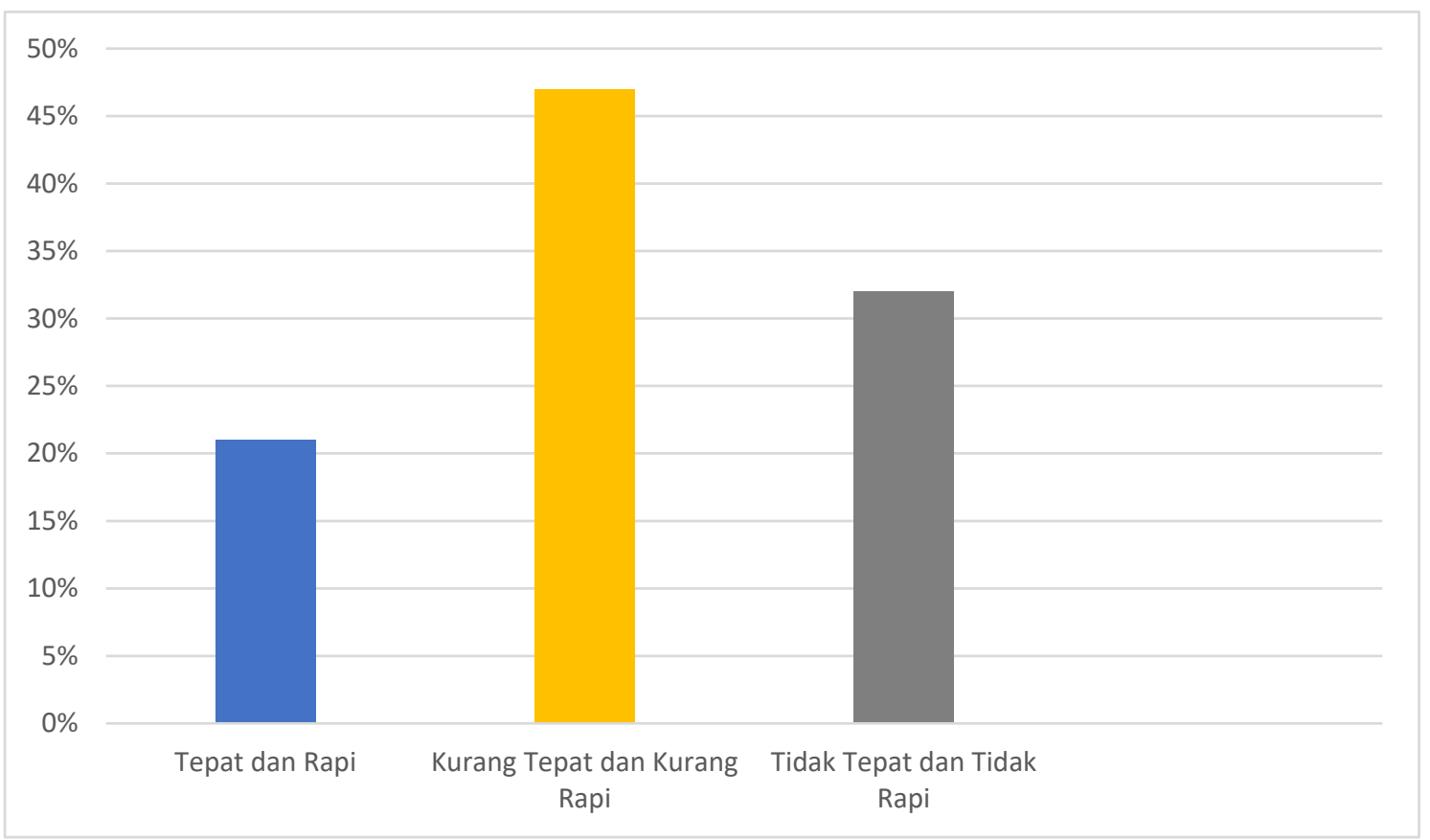

Berdasarkan gambar di atas, dapat ditangkap bahwa persentase tertinggi sebesar $47 \%$ qudrah mahasiswa semester I kelas A, B, C, dan D dalam menulis Al-Qur'an terdapat pada kategori kurang tepat dan kurang rapi dengan skor nilai tes tulis 70-84. Sedangkan mahasiswa dengan range skor nilai tes tulis 85-100 mendapat predikat tepat dan rapi berjumlah $21 \%$ dan predikat tidak tepat dan tidak rapi dengan range skor nilai tes tulis $<70$ sebesar $32 \%$.

Data qudrah mahasiswa dalam menulis Al-Qur'an diperkuat dengan hasil wawancara peneliti dengan beberapa mahasiswa yang mendapat predikat tepat dan rapi. Asal sekolah memegang peranan penting dalam menunjang qudrah mahasiswa dalam menulis Al-Qur'an. Mahasiswa dengan latar sekolah MA, MAN dan pondok pesantren terbiasa untuk menulis bahasa Arab karena mayoritas mata pelajaran menggunakan tulisan Arab.

Hal yang sama juga dirasakan mahasiswa UIN Alauddin Makassar dengan background pendidikan SMA dan SMK bahwa menulis Al-Qur'an atau kalimat yang berafiliasi pada huruf yang berbahasa arab bukanlah hal yang sederhana karena bentuk huruf yang begitu rumit sehingga tangan menjadi sangat kaku untuk mengukir huruf tersebut di atas kertas (Tahir, 2019).

Bersandarkan tes lisan dan tes tulis yang dilakukan masih banyak dijumpai kekeliruan dalam membaca dan menulis Al-Qur'an, misalnya kesalahan dalam melafadzkan huruf hijaiyah yang tidak selaras dengan makhrajnya, belum mampu mendeteksi bacaan yang harus dibaca panjang dan pendek, bacaan yang harus dibaca dengung dan samar. Ketidaksesuaian bacaan AlQur'an berimplikasi dalam hal menulis ayat Al-Qur'an, dibuktikan dengan adanya mahasiswa 
yang belum mampu memilah huruf yang dapat ditulis sambung dengan huruf yang tidak dapat disambung.

Hal yang sama juga ditemukan di Desa Bone Baru ketika pelaksanaan pelatihan Baca Tulis Al-Qur'an bahwa terdapat kekhilafan siswa dalam membaca dan menulis Al-Qur'an, seperti ada beberapa siswa yang masih mengeja dalam membaca Al-Qur'an, belum mampu mempraktekkan bacaan dengan tepat seperti bacaan yang seharusnya dibaca panjang justru dibaca pendek begitupun sebaliknya. Selain itu, adapula siswa yang belum mengetahui bacaan dengung. Ketika tes menulis huruf-huruf Al-Qur'an dengan cara didikte, siswa masih terlalu lamban dalam menangkap bacaan yang diucapkan dan keliru dalam memutuskan huruf apa yang harus ditulis (Bolong \& Aimang, 2018).

\section{KESIMPULAN}

Profil lulusan Program Studi Pendidikan Agama Islam diharapkan dapat menjadi guru agama yang profesional dengan ciri mampu membaca dan menulis Al-Qur'an dengan baik dan benar. Berdasarkan hasil tes lisan membaca Al-Qur'an yang dilakukan terlihat bahwa mayoritas mahasiswa semester I kelas A, B, C, dan D memiliki persentase tertinggi sebesar $49 \%$ terdapat pada kategori kurang lancar, predikat lancar berjumlah $31 \%$ dan predikat tidak lancar sebesar 20 $\%$. Untuk hasil tes tulis menunjukkan $47 \%$ terdapat pada kategori kurang tepat dan kurang rapi, predikat tepat dan rapi berjumlah $21 \%$ dan predikat tidak tepat dan tidak rapi sebesar $32 \%$. Adapun faktor yang cukup berpengaruh adalah motivasi dalam diri, asal sekolah, dan dorongan orang tua memegang peran penting dalam membentuk qudrah mahasiswa dalam membaca dan menulis Al-Qur'an karena membaca dan menulis adalah bagian dari keterampilan yang perlu diajarkan dan dilatih secara berkala. Kesimpulan dari penelitian menunjukkan bahwa kemampuan mahasiswa semester I Program Studi Pendidikan Agama Islam dalam membaca dan menulis Al-Qur'an masih kurang.

\section{DAFTAR PUSTAKA}

-, Z. (2019). PENERAPAN BACA TULIS AL-QUR'ANDENGAN METODE AL-BAYAN PADA MAHASISWA FAKULTAS KEDOKTERAN UNIVERSITAS YARSI JAKARTA. TAJDID : Jurnal Klmu Keislaman Dan Ushuluddin. https://doi.org/10.15548/tajdid.v17i2.126

Aeni, A. N. (2015). MENJADI GURU SD YANG MEMILIKI KOMPETENSI PERSONALRELIGIUS MELALUI PROGRAM ONE DAY ONE JUZ (ODOJ). Mimbar Sekolah 
Dasar. https://doi.org/10.17509/mimbar-sd.v2i2.1331

Akbar, D. (2019). Pengaruh Rutinitas Membaca Al-Qur'an Sebelum Belajar Terhadap Prestasi Belajar Pendidikan Agama Islam di Kelas VIII SMP Negeri 19 Palembang. Jurnal Intelektualita: Keislaman, Sosial Dan Sains. https://doi.org/10.19109/intelektualita.v8i1.4227

Aquami, A. (2017). Korelasi antara Kemampuan Membaca Al-Qur'andengan Keterampilan Menulis Huruf Arab pada Mata Pelajaran Al-Qur'anHadits di Madrasah Ibtidaiyah Quraniah 8 Palembang. JIP: Jurnal Ilmiah PGMI. https://doi.org/10.19109/jip.v3i1.1379

Ariani, S. (2017). Program Bengkel Mengaji (Upaya Peningkatan Kemampuan Tahsin AlQur'anMahasiswa PAI). Jurnal Mudarrisuna - Media Kajian Pendidikan Agama Islam. https://doi.org/10.22373/jm.v5i1.301

Bolong, Y. T., \& Aimang, H. A. (2018). PELATIHAN BACA TULIS ALQUR'AN DI TKA/TPA. MONSU'ANI TANO: Jurnal Pengabdian Masyarakat. https://doi.org/10.32529/tano.v1i1.244

Irawati, P., \& Lestari, M. S. (2017). Pengaruh Membaca Al-Qur'an terhadap Penurunan Tekanan Darah pada Klien dengan Hipertensi di RSK Dr. Sitanala Tangerang. Jurnal Ilmiah Keperawatan Indonesia (JIKI). https://doi.org/10.31000/JIKI.V1I1.281

KESUMA, G. C. (2016). PENERAPAN METODE IMLÂ' UNTUKMENINGKATKANKETERAMPILAN MENULIS BAHASA ARAB PESERTA DIDIK KELAS X SMA IT PONDOK PESANTREN AL-MUJTAMA'ALISLAMIKARANG ANYAR LAMPUNG SELATAN. Jurnal Al Bayan: Jurnal Jurusan Pendidikan Bahasa Arab. https://doi.org/10.24042/albayan.v8i2.363

Mar'ati, R., \& Chaer, M. T. (2017). Pengaruh Pembacaan dan Pemaknaan Ayat-ayat AlQur'anterhadap Penurunan Kecemasan pada Santriwati. Psikohumaniora: Jurnal Penelitian Psikologi. https://doi.org/10.21580/pjpp.v1i1.966

Nizhan, Abu. 2008. Buku Pintar Al-Qur'an. Jakarta: Qultum Media.

Suriah, M. (2018). Metode Yanbu' a untuk Meningkatkan Kemampuan Membaca Al-Quran pada Kelompok B-2 RA Permata Hati Al-Mahalli Bantul. Jurnal Pendidikan Madrasah.

Syarbini, Amirulloh dan Sumantri Jamhari. (2012). Kedahsyatan Membaca Al-Qur'an. Bandung: Ruang kata

Tahir, A. (2019). Implementasi Program BTQ pada Mahasiswa Jurusan Pendidikan Agama Islam Fakultas Tarbiyah dan Keguruan UIN Alauddin Makassar. Inspiratif Pendidikan. https://doi.org/10.24252/ip.v8i1.6915

Tim Laboratorium FTIK. 2015. Modul Baca Tulis Al-Qur'an. Tulungagung: IAIN Tulungagung. 
Wibawa, R. A. (2018). Pendidikan Baca Tulis Al-Quran (BTQ) di SMK Muhammadiyah Jawa Timur (Studi Kasus Pembelajaran BTQ di SMK Muhammadiyah 1 Taman Sidoarjo). Halaqa: Islamic Education Journal. https://doi.org/10.21070/halaqa.v2i2.1804 